\title{
Maintenance Program Guidelines for Programmatic Equipment
}

\author{
Prepared by \\ FACILITIES DEPARTMENT \\ $\&$ \\ OFFICE OF ASSESSMENT AND ASSURANCE
}

LAWRENCE BERKELEY LABORATORY

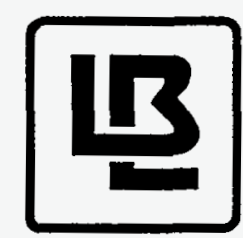

Prepared for the U.S. Department of Energy under Contract No. DE-AC-03-76SF00098

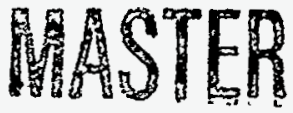

DSSTRIBUTION OF THIS DOCUMENT IS UNLIMITED

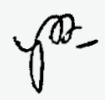




\section{DISCLAIMER}

This report was prepared as an account of work sponsored by an agency of the United States Government. Neither the United States Government nor any agency thereof, nor any of their employees, make any warranty, express or implied, or assumes any legal liability or responsibility for the accuracy, completeness, or usefulness of any information, apparatus, product, or process disclosed, or represents that its use would not infringe privately owned rights. Reference herein to any specific commercial product, process, or service by trade name, trademark, manufacturer, or otherwise does not necessarily constitute or imply its endorsement, recommendation, or favoring by the United States Government or any agency thereof. The views and opinions of authors expressed herein do not necessarily state or reflect those of the United States Government or any agency thereof. 


\section{DISCLAIMER}

Portions of this document may be illegible in electronic image products. Images are produced from the best available original document. 


\section{Contents}

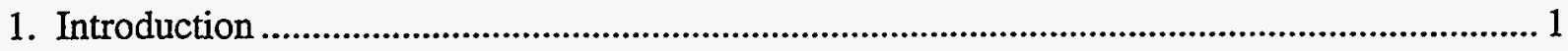

2. Elements of a Programmatic Equipment Maintenance Program ................................................ 3

2.1. Identification and Grading of the Programmatic Equipment ....................................... 3

2.2. Maintenance Requirements and Procedures ………............................................... 5

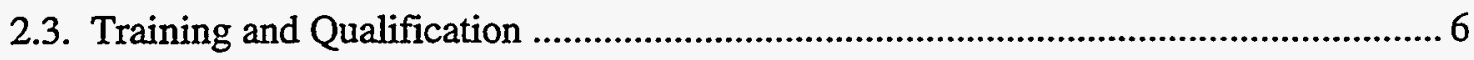

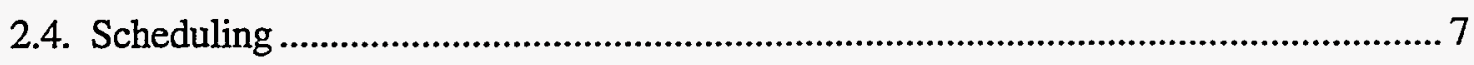

2.5. Equipment Repair History ..............................................................................

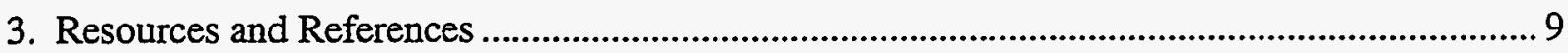

Attachment I: Graded Approach to Maintenance Determination Risk-Level Definitions ........... 11

Attachment II: Examples of Programmatic Equipment Risk Categorization ............................... 13

Attachment III: Implementation of Graded Approach for Maintenance Program Elements ............................................................................................. 15

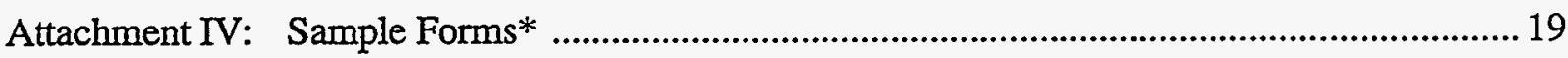

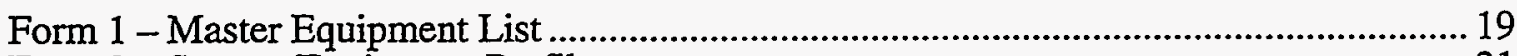

Form 2 - System/Equipment Profile ……………………............................................. 21

Form 3 - Maintenance Needs Evaluation .............................................................................. 23

Form 4 - Maintenance Program/Schedule ............................................................................2 25

Form 5 - Equipment Maintenance Record ............................................................................ 27

*NOTE: All forms are available in hard copy or electronically from the Facilities Department. Contact the Work Request Center to obtain the forms. 


\section{Introduction}

The Division Directors at Lawrence Berkeley Laboratory are responsible for implementing a maintenance program for research equipment (also referred to as programmatic equipment) assigned to them. The program must allow maintenance to be accomplished in a manner that promotes operational safety, environmental protection and compliance, and cost effectiveness; that preserves the intended functions of the facilities and equipment; and that supports the programmatic mission of the Laboratory.

Programmatic equipment-such as accelerators, lasers, radiation detection equipment, and glove boxes-is dedicated specifically to research. Installed equipment, by contrast, includes the mechanical and electrical systems installed as part of basic building construction, equipment essential to the normal functioning of the facility and its intended use. Examples of installed equipment are heating, ventilating, and air conditioning systems; elevators; and communications systems.

The LBL Operating and Assurance Program Plan (PUB-3111, Revision 4) requires that a maintenance program be prepared for programmatic equipment and defines the basic maintenance program elements. Such a program of regular, documented maintenance is vital to the safety and quality of research activities, for the following reasons:

- It reduces lost research time caused by equipment failure.

- It prevents hazardous conditions from developing that have the potential for damaging the environment or endangering the health and safety of employees.

- It lessens the likelihood of regulatory violations or reportable occurrences that could lead to fines or loss of funding.

- It provides for continuity of safety and assurance of proper maintenance between different users of a given system or piece of equipment.

Maintenance of programmatic equipment is the responsibility of the operating organizations, since those organizations are responsible for maintaining the value and functionality of Laboratory equipment under their care. The Facilities Department and the Office of Assessment and Assurance (OAA), however, provide direct support to researchers in developing, implementing, and documenting maintenance programs for their research equipment.

As a part of that support, this document offers guidance to Laboratory organizations for developing their maintenance programs. It clarifies the maintenance requirements of the Operating and Assurance Program (OAP) and presents an approach that, while not the only possibility, can be expected to produce an effective maintenance program for research equipment belonging to the Laboratory's organizations.

The maintenance program requirements are primarily implemented through and documented in Facility and Project Notebooks. This document should be used in conjunction with the instruction manuals for those Notebooks, which are attachments to LBL Procedure OAP-IP-001, Preparation and Maintenance of LBL Notebooks.

It should be stressed that the maintenance program addresses only equipment maintenance, not its operation. On the other hand, Activity Hazard Documents (AHDs), Radiological 
Work Authorizations (RWAs), and Radiological Work Permits (RWPs) address mitigation of risks associated with the operation of highly hazardous equipment. AHDs also contain information on maintenance activities that affect risk mitigation. 


\section{Elements of a Programmatic Equipment Maintenance Program}

As described in the OAP, an efficient maintenance program for research equipment has five basic elements. Detailed guidance for each element follows.

\subsection{Identification and Grading of the Programmatic Equipment}

Programmatic equipment must be identified, inventoried, and graded against DOE's established risk categories. This process enables a graded approach to maintenance, in which resources for maintenance are allocated according the level of risk associated with possible failures of a given system or piece of equipment. This risk determination also controls the rigor required for performing the maintenance.

To determine the relative risk associated with the organization's programmatic equipment, each system, subsystem, piece of equipment, or component must be evaluated against the four risk categories defined in Attachment I. (Examples of equipment in each risk category are provided in Attachment II.) In determining risk categories for equipment, two important points should be kept in mind:

1. Currently no systems or equipment at LBL fall into Category 1 (critical). If you believe you have discovered such a system, contact the Facilities Department immediately.

2. Category 4 (low) equipment consists typically of items such as office equipment and furniture, personal computers, or desktop centrifuges, whose failure would have negligible consequences.

\section{Note}

Once graded and identified, Category 4 equipment is not subject to the requirements of the last four elements of the maintenance program.

Consider the following grading concepts when determining risk category:

- Grade systems by components:

Break major systems down into their significant subsystems and components whenever possible, as different components may require different levels of maintenance. At a minimum, the system must be broken down to a level of detail sufficient to support resource allocation decisions.

Rather than using the highest level of maintenance for an entire system, it may be possible to use it for a single critical component. This almost always results in significant savings.

Note that safe operation of a given piece of equipment often depends on other safety systems, which must also be identified for proper maintenance. 
- Base the evaluation on the consequence of equipment failure:

Keep in mind that risk grading is based on the consequence of equipment failure, not on whether equipment operation is hazardous.

- Use worst-case, credible scenario:

Consider the realistic probability of potential failures in this rating. Do not rate according to what could happen if equipment failure coincided, for example, with both a severe earthquake and the maximum local 100-year rainfall.

- Don't overcommit:

Equipment must be classified accurately. Avoid overestimating hazards "to be on the safe side." A higher level of maintenance costs research programs more time and money.

- Keep in mind that equipment application defines category:

Identical pieces of equipment could be graded in different categories because of differing applications and consequences of failure.

- Remember, if it isn't risk Category 4, it's probably risk Category 3:

After eliminating items that obviously fall into risk Category 4, it may be useful to begin by assuming that the remaining equipment being evaluated falls into Category 3 , the most common category at LBL. Subsequently, equipment can be moved to Category 2 if significant justification exists, or it can be reduced to Category 4 if closer consideration reveals that the consequences of maintenance failure would be negligible.

After risk categories have been assigned to all programmatic equipment and systems, an inventory should be compiled of those items assigned to risk Categories 2 and 3 . This inventory becomes the Master Equipment List (MEL). Keep in mind that Category 4 equipment does not need to be included.

The MEL becomes the foundation for the programmatic equipment maintenance program. At a minimum, the MEL includes:

- A description of the system or equipment.

- The LBL/DOE Property Identification Number, if one has been assigned.

- The location (building and room) of the system or equipment.

- The risk category assigned in the grading process.

- Identification of any related hazardous materials and/or safety systems that might impact maintenance activities.

An example of a completed Master Equipment List is contained in Attachment IV (Form 1). Electronic or hard-copy versions of this form are available from the Facilities Department's Work Request Center. Other formats are acceptable, but all information contained on the 
sample form must be included. The assigned risk category should be the basis for the order in which the maintenance program development process is completed for the equipment inventoried.

The Master Equipment List must be included or referenced in Section 1.5 of the applicable Facility Notebook or Section 3.14 of the applicable Project Notebook.

\subsection{Maintenance Requirements and Procedures}

Details of the required maintenance for equipment and systems will be developed from the assessment described in Section 2.1 and from equipment characteristics recorded by completing a System/Equipment Profile form and a Maintenance Needs Evaluation form. Completed examples of these forms are contained in Attachment IV (Forms 2 and 3).

\section{System/Equipment Profile}

General information for each piece of equipment identified and included in the Master Equipment List should be recorded on a Facilities Department System/Equipment Profile form or a similar document.

It is important to clarify the boundary between programmatic equipment (maintained by the operating organization) and installed equipment (maintained by the Facilities Department) to ensure that responsibility for maintenance is well defined.

Special attention should be paid to hazardous equipment and to mitigation devices whose failure could result in hazardous conditions. An AHD may have been completed for a particular piece of equipment or experiment. Hazard mitigation components identified in the AHD must be included in the maintenance management plan.

\section{Maintenance Needs Evaluation}

Current general overall maintenance information should be collected and recorded on a Maintenance Needs Evaluation form or other suitable document, and details about special maintenance requirements should be provided.

The risk category of the equipment, the identified frequency of use, and other special requirements will determine what maintenance activities should be performed and what frequency will be required.

Equipment technical manuals, if supplied by the vendor, are an excellent tool to use in evaluating maintenance needs. The Facilities Department Maintenance and Operations (M\&O) staff can be of assistance in recommending maintenance frequencies consistent with the risk category, frequency of use, and industrial standards. The schedule for equipment maintenance can be recorded on the Maintenance Program/Schedule form, an example of which is contained in Attachment IV (Form 4).

In some cases, a description, written to the level of detail necessary to direct the work and to ensure that maintenance is done safely and efficiently, may be sufficient. In other instances, 
formal written maintenance procedures may be required if indicated by the relative risk category of the equipment/system or the complexity of the maintenance to be performed. Such written procedures may be found in manufacturers' manuals or may be developed for specific application to LBL practices.

Factors that should be considered in describing maintenance requirements and writing maintenance procedures include:

- Lockout/tagout requirements.

- Qualifications required for personnel performing the maintenance.

- Use of proper tools and equipment.

- Confined space entry.

- Identification of operations requiring authorization: entering controlled areas, removing power from ventilation fans, etc.

- Post-maintenance testing, if required, to confirm that the system/equipment is operating properly before being returned to service following maintenance.

- Configuration control elements; for example, where valves or switches must be balanced for safe use.

- Modification of adjustment procedures if, for example, parts replaced during maintenance behave differently from those they replace.

- Preservation of the terms of warranty or guarantees for equipment by ensuring that all maintenance and repair is within the terms of the warranty.

- Requirements for safety systems and equipment such as interlocks, radiation monitors, etc.

- Prevention of the introduction of suspect or counterfeit parts.

Equipment in risk Category 2 may require equipment-specific, detailed procedures that include such elements as identification of required tools and support equipment, personnel training and qualification requirements, specification of calibrated measurement and test equipment, and documented post-maintenance testing. The Facilities Department M\&O Engineer should be consulted for assistance in evaluating the need for and development of such procedures.

Completed forms and any written procedures covering maintenance of programmatic equipment should be included or referenced in Section 3.4.2 of the applicable Facility Notebook or Section 3.14 of the applicable Project Notebook.

\subsection{Training and Qualification}

Maintenance must be performed by personnel with knowledge, skills, training, and certifications commensurate with the consequences of the equipment to be maintained; the maintenance must also be performed in accordance with normal industrial standards. Use the Maintenance Needs Evaluation form (Attachment IV, Form 3) to record whether 
maintenance actions will be performed through a service contract, Facilities Department M\&O personnel, or by in-house personnel.

The risk category of the equipment and special training requirements identified on the Maintenance Needs Evaluation form will determine the level of training, certification, and qualification required for the personnel maintaining the equipment. For risk Category 2 equipment, maintenance and repair skills and training must be documented and provided or referenced in the appropriate Project or Facility Notebook. At lower risk categories, basic technician skills are acceptable.

Any special training required, as well as a list of personnel trained and qualified to perform maintenance activities, must be included or referenced in Sections 2.3, 2.4, and 2.5 of the applicable Facility Notebook or Sections 2.2 and 2.4 of the applicable Project Notebook.

\subsection{Scheduling}

Preventive maintenance and repair should be scheduled and coordinated to ensure that maintenance activities are performed efficiently, in the proper sequence, and within prescribed time limits. Resources should be allocated in a manner to ensure that risk Category 2 systems and equipment receive priority scheduling.

Routine maintenance should be carefully coordinated with operating schedules to minimize interruptions to research or support activities. Such scheduling is particularly important when organizations other than the operating organization are performing the maintenance activity.

It is also important that scheduling of routine maintenance take into account the availability of the necessary tools, equipment, and parts to complete the maintenance activity. An adequate supply of tools, equipment, and spare parts for high-risk (Category 2) equipment and systems should always be available for emergency maintenance.

Arrangements can be made through the Facilities Department Work Request Center for equipment maintenance to be included in LBL's Predictive and Preventive Maintenance System, which automatically schedules maintenance based on predetermined frequencies. Requests for the Facilities Department to perform nonroutine maintenance should be routed through the Work Request Center.

Special maintenance jobs-such as pressure regulator calibration, arranged through the Regulator Shop-should also be routed through the Work Request Center.

A description of how maintenance activities are scheduled should be included in Section 3.4.3 of the applicable Facility Notebook or in Section 1.5 of the applicable Project Notebook.

\subsection{Equipment Repair History}

A system for storing historical maintenance data, both scheduled preventive maintenance and repairs (corrective), must be established and maintained. The objects of this system are to enable technicians and managers to readily retrieve maintenance information for analysis 
of equipment performance and to provide continuity among different users of the system or equipment.

A review of the equipment/system repair history may reveal patterns of problems, which can lead to earlier solutions. At a minimum, the documentation should be reviewed just before performing maintenance to help ensure that the steps taken will solve the problem being addressed.

Regular analysis of equipment repair records may also lead to changes in the scheduling of predictive maintenance; i.e., "as-needed" planned maintenance performed prior to projected equipment failure based on repair history. Safety, risk, and reliability are the determining factors in applying predictive maintenance to high-risk-category equipment.

The repair history system can be as simple as an equipment or maintenance logbook. At a minimum, the following information must be recorded:

- The date and description of the problem.

- A detailed description of the repairs or maintenance performed.

- The name of the technician, organization, or contractor performing the repairs.

- A list of the parts and materials used.

- Confirmation of post-maintenance testing, if it was required.

Alternatively, a form such as the Equipment Maintenance Record, an example of which is contained in Attachment IV (Form 5), or an electronic maintenance database can be used. Repair history information should be included (or referenced) in Section 4.4 of the applicable Facility Notebook or Section 4.3 of the applicable Project Notebook.

If maintenance is arranged through the Facilities Department M\&O Section, maintenance will be scheduled through the Laboratory Predictive and Preventive Maintenance System and the results recorded in the Repair History System. 


\section{Resources and References}

Facilities Department M\&O Section

Facilities Department Work Request Center

Office of Assessment and Assurance

DOE Order 4330.4B, Maintenance Management Program

Contract DE-ACO3-765F00098 between the University of California and the Department of Energy, Appendix E

LBL Operating and Assurance Program Plan (PUB-3111)

Preparation and Maintenance of LBL Notebooks (LBL Procedure OAP-IP-001) 
•

. 


\section{Attachment I}

Graded Approach to Maintenance Determination Risk-Level Definitions

\begin{tabular}{|c|c|c|c|c|c|}
\hline \multirow{2}{*}{\multicolumn{2}{|c|}{ Risk Area }} & \multicolumn{4}{|c|}{ RISK CATEGORY } \\
\hline & & \multirow{2}{*}{$\begin{array}{l}\qquad 1 \text { (critical) } \\
\text { Potential death or } \\
\text { serious injury to a } \\
\text { member of the } \\
\text { public }\end{array}$} & \multirow{2}{*}{\begin{tabular}{l}
\multicolumn{1}{|c}{2 (high) } \\
$\begin{array}{l}\text { Major injury, } \\
\text { irritation, or } \\
\text { annoyance }\end{array}$
\end{tabular}} & \multirow{2}{*}{\begin{tabular}{|c|}
3 (medium) \\
No public impact
\end{tabular}} & \multirow{2}{*}{$\frac{4 \text { (low) }}{\text { No public impact }}$} \\
\hline $\mathbf{A}$ & Public Safety & & & & \\
\hline B & Employee Safety & & $\begin{array}{l}\text { Potential death or } \\
\text { serious (disabling) } \\
\text { injury or illness of } \\
\text { Lab worker }\end{array}$ & $\begin{array}{l}\text { Minor illness or } \\
\text { injury }\end{array}$ & $\begin{array}{l}\text { No injury or } \\
\text { illness }\end{array}$ \\
\hline $\mathrm{C}$ & $\begin{array}{l}\text { Environmental } \\
\text { Consequences }\end{array}$ & $\begin{array}{l}\text { Severe damage to } \\
\text { the environment } \\
\text { beyond } \\
\text { boundaries of } L a b\end{array}$ & $\begin{array}{l}\text { Localized } \\
\text { contamination, } \\
\text { requiring cleanup } \\
\text { within Lab } \\
\text { boundaries }\end{array}$ & $\begin{array}{l}\text { Contamination } \\
\text { limited to } \\
\text { immediate facility } \\
\text { area requiring } \\
\text { minor cleanup }\end{array}$ & $\begin{array}{l}\text { Contamination } \\
\text { release within } \\
\text { allowable limits; } \\
\text { no cleanup }\end{array}$ \\
\hline D & $\begin{array}{l}\text { Safeguards \& } \\
\text { Security }\end{array}$ & & $\begin{array}{l}\text { May allow loss or } \\
\text { theft of Category } \\
1 \text { quantities of } \\
\text { SNM or national } \\
\text { security } \\
\text { information }\end{array}$ & $\begin{array}{l}\text { May allow loss or } \\
\text { theft of Category } \\
2 \text { or } 3 \text { quantities } \\
\text { of SNM or } \\
\text { classified } \\
\text { information }\end{array}$ & $\begin{array}{l}\text { No loss of SNM } \\
\text { or secure data }\end{array}$ \\
\hline $\mathbf{E}$ & $\begin{array}{l}\text { Mission/ } \\
\text { Economic } \\
\text { Impact }\end{array}$ & & $\begin{array}{l}\text { May result in total } \\
\text { loss of major } \\
\text { process capability; } \\
\text { or severe mission } \\
\text { or economic } \\
\text { impact }\end{array}$ & $\begin{array}{l}\text { Damage to a } \\
\text { facility or process } \\
\text { with serious } \\
\text { mission or } \\
\text { economic impact }\end{array}$ & $\begin{array}{l}\text { No damage, or } \\
\text { minor damage } \\
\text { resulting in } \\
\text { inconvenience }\end{array}$ \\
\hline
\end{tabular}

NOTE: The risk category assigned to a system or piece of equipment should be that of the highest applicable level (1 through 4 ) identified through the risk prioritization process for that system or piece of equipment. 


\section{Attachment II}

\section{Examples of Programmatic Equipment Risk Categorization}

Evaluate based on the consequence of failure due to lack of maintenance, not hazardousness of use or consequences of misuse. These are illustrative examples, not a comprehensive list.

\begin{tabular}{|c|c|c|c|}
\hline $\begin{array}{l}\text { Risk } \\
\text { Category }\end{array}$ & $\begin{array}{l}\text { Risk } \\
\text { Area }\end{array}$ & $\begin{array}{l}\text { System/Equipment } \\
\text { Description }\end{array}$ & Consequence of Equipment Failure \\
\hline Critical & \multicolumn{3}{|c|}{ NOTE: LBL should have no Category 1 risk-level equipment. } \\
\hline (1) & $\mathbf{A}$ & $\mathrm{Pu}^{239}$ Facility & This equipment is not used at $\mathrm{LBL}$. \\
\hline \multirow[t]{7}{*}{$\begin{array}{l}\text { High } \\
(2)\end{array}$} & $\mathbf{B}$ & $\begin{array}{l}\text { Offsite research, } \\
\text { demonstrations; e.g., } \\
\text { geothermal involving } \\
\text { explosives }\end{array}$ & Public injury, irritation, or annoyance. \\
\hline & $\mathbf{B}$ & $\begin{array}{l}\text { Toxic gas detection } \\
\text { system }\end{array}$ & $\begin{array}{l}\text { Failure of equipment to detect presence of toxic gas } \\
\text { could result in serious illness or death. }\end{array}$ \\
\hline & $\mathbf{B}$ & $\begin{array}{l}\text { Class IV laser } \\
\text { interlock system }\end{array}$ & $\begin{array}{l}\text { Failure of interlock system could result in exposure to a } \\
\text { light beam of an intensity sufficient to cause permanent } \\
\text { damage to vision. }\end{array}$ \\
\hline & $\mathbf{C}$ & $\begin{array}{l}\text { High-pressure gas } \\
\text { regulating system } \\
\left(\text { e.g., } \mathrm{N}_{2}\right)\end{array}$ & $\begin{array}{l}\text { Equipment failure leading to excessive pressure buildup } \\
\text { could result in serious injury. }\end{array}$ \\
\hline & $\mathbf{E}$ & $\begin{array}{l}\text { Positive displacement } \\
\text { pump }\end{array}$ & $\begin{array}{l}\text { Failure of pump used for concentrated acid, toxic } \\
\text { chemicals or radioactive solutions could result in a } \\
\text { hazardous spill requiring cleanup within Laboratory } \\
\text { boundaries. }\end{array}$ \\
\hline & $\mathbf{E}$ & $\begin{array}{l}\text { Ultralow freezer } \\
\text { (containing multiple } \\
\text { years' samples) }\end{array}$ & $\begin{array}{l}\text { Thawing of samples could have severe, irreversible } \\
\text { research impact; i.e., serious program mission impact. }\end{array}$ \\
\hline & $\mathbf{E}$ & $\begin{array}{l}\text { Laser measuring } \\
\text { device }\end{array}$ & $\begin{array}{l}\text { Could be extremely expensive and time consuming to } \\
\text { set up. }\end{array}$ \\
\hline
\end{tabular}




\section{Examples of Programmatic Equipment Risk Categorization (Continued)}

\begin{tabular}{|c|c|c|c|}
\hline $\begin{array}{c}\text { Risk } \\
\text { Category }\end{array}$ & $\begin{array}{l}\text { Risk } \\
\text { Area }\end{array}$ & $\begin{array}{l}\text { System/Equipment } \\
\text { Description }\end{array}$ & Consequence of Equipment Failure \\
\hline \multirow[t]{6}{*}{$\begin{array}{l}\text { Medium } \\
\text { (3) }\end{array}$} & B & $\begin{array}{l}\text { Compressed gas } \\
\text { regulators }\end{array}$ & $\begin{array}{l}\text { Failure to calibrate compressed gas regulators properly } \\
\text { can result in serious injury. }\end{array}$ \\
\hline & $\mathbf{C}$ & Ultracentrifuge & Possible injury may result from inadequate maintenance. \\
\hline & $\mathbf{E}$ & $\begin{array}{l}\text { Laboratory vacuum } \\
\text { pump for glove boxes }\end{array}$ & $\begin{array}{l}\text { Potential contamination, limited to the facility, if } \\
\text { isolation valves don't function and negative pressure } \\
\text { fails. }\end{array}$ \\
\hline & $\mathbf{E}$ & $\begin{array}{l}\text { Ultralow freezer } \\
\text { (containing recent } \\
\text { samples, chemicals) }\end{array}$ & $\begin{array}{l}\text { Thawing due to improper freezer maintenance could } \\
\text { have serious impact on research projects. }\end{array}$ \\
\hline & $\mathbf{E}$ & $\begin{array}{l}\text { Data storage, } \\
\text { acquisition, and } \\
\text { computer control } \\
\text { systems }\end{array}$ & $\begin{array}{l}\text { Potential for loss of valuable data or serious impact on } \\
\text { Laboratory processes or the program's mission. }\end{array}$ \\
\hline & $\mathbf{E}$ & Electron microscope & $\begin{array}{l}\text { Equipment failure could cause loss of use or damage to } \\
\text { expensive, delicate equipment. }\end{array}$ \\
\hline \multirow[t]{5}{*}{$\begin{array}{l}\text { Low } \\
(4)\end{array}$} & \multicolumn{3}{|r|}{ opriate logbooks or notebooks. } \\
\hline & All & $\begin{array}{l}\text { Office equipment, } \\
\text { furniture, and personal } \\
\text { computers }\end{array}$ & $\begin{array}{l}\text { Specifically excluded from inventory requirement by } \\
\text { DOE. }\end{array}$ \\
\hline & All & $\begin{array}{l}\mathrm{pH} \text { meter for general } \\
\text { lab use }\end{array}$ & $\begin{array}{l}\text { Equipment failure consequence negligible but routine } \\
\text { calibration essential to accuracy. }\end{array}$ \\
\hline & All & Mettler balance & $\begin{array}{l}\text { Equipment failure consequence negligible but routine } \\
\text { calibration maintenance essential to accuracy. }\end{array}$ \\
\hline & All & Desktop centrifuge & Minimal hazards likely. \\
\hline
\end{tabular}




\section{Attachment III}

\section{Implementation of Graded Approach for Maintenance Program Elements}

This document is intended to show the range of actions to be taken for each maintenance element at different risk categories. It is not intended to provide specific instructions. Tailor details to your particular equipment or system.

\begin{tabular}{|c|c|c|c|}
\hline \multirow{2}{*}{$\begin{array}{l}\text { Maintenance Program } \\
\text { Elements }\end{array}$} & \multicolumn{3}{|c|}{ Risk Category } \\
\hline & High (2) & Medium (3) & Low (4) \\
\hline \multicolumn{4}{|l|}{ IENTEYY/GRADE } \\
\hline Master Equipment List & $\begin{array}{l}\text { High-risk equipment } \\
\text { listed, required data } \\
\text { obtained and on line }\end{array}$ & $\begin{array}{l}\text { Production equipment } \\
\text { listed, critical data } \\
\text { available }\end{array}$ & $\begin{array}{l}\text { Balance of plant and } \\
\text { infrastructure equipment } \\
\text { listed, data on file }\end{array}$ \\
\hline \multicolumn{4}{|l|}{$\begin{array}{l}\text { MAINT PROCEDURESI } \\
\text { REQUTREMENTS }\end{array}$} \\
\hline Maintenance Procedures & $\begin{array}{l}\text { Detailed specific } \\
\text { procedures - written in } \\
\text { coordination with AHDs, } \\
\text { if an AHD is required. }\end{array}$ & $\begin{array}{l}\text { Some general procedures } \\
\text { needed }\end{array}$ & $\begin{array}{l}\text { Industrial practice, skill } \\
\text { of craft }\end{array}$ \\
\hline Post-Maintenance Testing & $\begin{array}{l}\text { Requirements specified in } \\
\text { maintenance procedures, } \\
\text { performance documented }\end{array}$ & Limited to safety systems & $\begin{array}{l}\text { Normal industrial } \\
\text { practice }\end{array}$ \\
\hline $\begin{array}{l}\text { Control and Calibration of } \\
\text { Measuring and Test } \\
\text { Equipment }\end{array}$ & $\begin{array}{l}\text { High calibration } \\
\text { standards and frequency }\end{array}$ & Practice documented & Qualitative use only \\
\hline $\begin{array}{l}\text { Modification Work/ } \\
\text { Configuration Control }\end{array}$ & $\begin{array}{l}\text { Modifications controlled, } \\
\text { impacts to maintenance } \\
\text { documented, coordinated } \\
\text { with AHD and included } \\
\text { in Notebook }\end{array}$ & $\begin{array}{l}\text { Limited configuration } \\
\text { control for safety } \\
\text { systems only }\end{array}$ & $\begin{array}{l}\text { Unnecessary; no safety } \\
\text { systems at this hazard } \\
\text { level }\end{array}$ \\
\hline \multicolumn{4}{|c|}{ IRAINING } \\
\hline Training and Certification & $\begin{array}{l}\text { Rigorously document } \\
\text { maintenance and repair } \\
\text { skills; document or verify } \\
\text { training; develop training } \\
\text { and qualification } \\
\text { programs }\end{array}$ & $\begin{array}{l}\text { Document maintenance } \\
\text { and repair skills; } \\
\text { document or verify } \\
\text { training, on-the-job- } \\
\text { training }\end{array}$ & $\begin{array}{l}\text { Utilize basic technician } \\
\text { skills }\end{array}$ \\
\hline
\end{tabular}




\section{Implementation of Graded Approach for Maintenance Program Elements (Continued)}

\begin{tabular}{|c|c|c|c|}
\hline \multirow{2}{*}{$\begin{array}{l}\text { Maintenance Program } \\
\text { Elements }\end{array}$} & \multicolumn{3}{|c|}{ Risk Category } \\
\hline & High (2) & Medium (3) & Low (4) \\
\hline \multicolumn{4}{|c|}{ SCREDUTE } \\
\hline $\begin{array}{l}\text { Priority System for } \\
\text { M\&O/Contract Maint }\end{array}$ & Priority system required & Optional & Unnecessary \\
\hline Scheduling Systems & $\begin{array}{l}\text { Formally scheduled, } \\
\text { monitored by managers }\end{array}$ & Optional & Unnecessary \\
\hline $\begin{array}{l}\text { Job Planning \& Estimating } \\
\text { for M\&O / Contract Maint }\end{array}$ & $\begin{array}{l}\text { Detailed planning from } \\
\text { beginning through post- } \\
\text { maintenance testing }\end{array}$ & $\begin{array}{l}\text { Minimal procedures for } \\
\text { processes with safety } \\
\text { implications }\end{array}$ & Unnecessary \\
\hline Repair Priority / Spare Parts & $\begin{array}{l}\text { Scheduled high priority, } \\
\text { parts in stock, long-lead } \\
\text { items in stock }\end{array}$ & Not required & Unnecessary \\
\hline Requisitioning/ Procurement & $\begin{array}{l}\text { Review the need for on- } \\
\text { hand spare parts for safety } \\
\text { components }\end{array}$ & Off-shelf & Off-shelf \\
\hline BackJog Work Control & $\begin{array}{l}\text { Deferred work formally } \\
\text { justified }\end{array}$ & $\begin{array}{l}\text { Deferred work reviewed } \\
\text { and prioritized }\end{array}$ & Not required \\
\hline \multicolumn{4}{|c|}{ REPAIRHISTORY } \\
\hline $\begin{array}{l}\text { Repair History \& Vendor } \\
\text { Information }\end{array}$ & Required & Required & Not required \\
\hline $\begin{array}{l}\text { Work Request System for } \\
\text { M\&O/Contract Maint }\end{array}$ & $\begin{array}{l}\text { M\&O work to be handled } \\
\text { through the M\&O job } \\
\text { order system } \\
\text { Contracted maintenance } \\
\text { to be handled through the } \\
\text { LBL procurement process } \\
\text { Work done by program to } \\
\text { have an appropriately } \\
\text { detailed work package }\end{array}$ & $\begin{array}{l}\text { M\&O work to be } \\
\text { handled through the } \\
\text { M\&O job order system } \\
\text { Contracted maintenance } \\
\text { to be handled through the } \\
\text { LBL procurement } \\
\text { process }\end{array}$ & $\begin{array}{l}\text { M\&O work to be } \\
\text { handled through the } \\
\text { M\&O job order system }\end{array}$ \\
\hline
\end{tabular}




\section{Implementation of Graded Approach for Maintenance Program Elements (Continued)}

\begin{tabular}{|c|c|c|c|}
\hline \multirow{2}{*}{$\begin{array}{c}\text { Maintenance Program } \\
\text { Elements }\end{array}$} & \multicolumn{3}{|c|}{ Risk Category } \\
\hline & High (2) & Medium (3) & Low (4) \\
\hline \multicolumn{4}{|c|}{$\begin{array}{l}\text { REPAnR HIST́̈RY } \\
\text { (Continued) }\end{array}$} \\
\hline Predictive Maintenance & $\begin{array}{l}\text { Data gathered on } \\
\text { equipment operation, } \\
\text { trended and analyzed }\end{array}$ & $\begin{array}{l}\text { Selective use for } \\
\text { production or high-cost } \\
\text { equipment }\end{array}$ & Not required \\
\hline $\begin{array}{l}\text { Analysis of Root Cause of } \\
\text { Problems }\end{array}$ & $\begin{array}{l}\text { Determination of cause } \\
\text { and follow-up analysis } \\
\text { required }\end{array}$ & Selectively utilized & Not required \\
\hline \multicolumn{4}{|c|}{$\begin{array}{l}\text { MAINTENANCE QUALITY } \\
\text { ASSURÄNCE }\end{array}$} \\
\hline $\begin{array}{l}\text { Performance Measurement } \\
\text { and Improvement }\end{array}$ & $\begin{array}{l}\text { Performance indicators } \\
\text { focus on safe } \\
\text { maintenance operations }\end{array}$ & $\begin{array}{l}\text { Performance indicators } \\
\text { focus on safe, cost- } \\
\text { effective maintenance }\end{array}$ & $\begin{array}{l}\text { Performance indicators } \\
\text { focus on safe, cost- } \\
\text { effective maintenance }\end{array}$ \\
\hline Management Involvement & $\begin{array}{l}\text { Line managers } \\
\text { knowledgeable, qualified, } \\
\text { and involved }\end{array}$ & $\begin{array}{l}\text { Line managers } \\
\text { knowledgeable and } \\
\text { involved }\end{array}$ & Line managers involved \\
\hline Periodic Review and Analysis & $\begin{array}{l}\text { Periodic self-assessment } \\
\text { of maintenance support, } \\
\text { EH\&S to provide } \\
\text { oversight }\end{array}$ & $\begin{array}{l}\text { Review of operation by } \\
\text { line management }\end{array}$ & Not required \\
\hline
\end{tabular}





\section{is Master Equipment List (MEL)}

\begin{tabular}{|l|l|c|c|c|c|c|c|}
\hline \multicolumn{2}{|l|}{ Division: MSD } & Principal Investigator: Jack Armstrong & Date: \\
\hline \hline $\begin{array}{c}\text { Item } \\
\text { No. }\end{array}$ & System/Equip. Description & $\begin{array}{c}\text { Property } \\
\text { ID No. }\end{array}$ & Bldg. & Room & $\begin{array}{c}\text { Hazardous } \\
\text { Material(s) }\end{array}$ & $\begin{array}{c}\text { Risk } \\
\text { Level }\end{array}$ & Related Safety Systems \\
\hline \hline 1 & MOCVD Reactor & 6146770 & 2 & 256 & yes & 2 & Sealed radioactive sources, LN, LHe, \\
\hline 2 & Exhaust gas conditioner (CDO) & 6219982 & 2 & 238 & yes & 2 & gas detectors, sensors, mist chamber \\
\hline 3 & Surgical laser system & 6253801 & $70 A$ & 4431 & yes & 2 & smoke detectors, alarms, sensors \\
\hline 4 & Articulating arm & 6253795 & $70 A$ & 4431 & yes & 2 & smoke detectors, alarms, sensors \\
\hline 5 & Parr reactor vessel & n/a & 70 & 274 & yes & 2 & sensors, press. relief valves, gauges \\
\hline 6 & Laser \#1, Nd-YAG & 6135039 & 3 & 118 & yes & 2 & sensors, press. relief valves, gauges \\
\hline 7 & Laser \#2, dye & 6149234 & 3 & 118 & yes & 2 & sensors, press. relief valves, gauges \\
\hline 8 & Laser \#3, dye & 6039764 & 3 & 118 & yes & 2 & sensors, press. relief valves, gauges \\
\hline
\end{tabular}





\section{ATTACHMENT IV (FORM 2) - SAMPLE SYSTEM/EQUTPMENT PROFILE}

\section{System/Equipment Profile}

General System/Equipment Information

Description MOCVD Reactor

Manufacturer Emcore

Model GS 3000

Property ID No. 6146770

Serial No. N/A

Acquisition Date 1989

Pr. Investigator Jack Armstrong

Div: MSD Bldg 2

Room 256

Connections / Interface of Programmatic Equipment to LBL Facility Utilities

$\square$ Water $\square$ Gas/ventilation $\square$ Sanitary sewer $\square$ Other

$\square$ LCW $\square \quad$ Vacuum $\square$ Acid waste $\otimes$ None

\section{Hazards and Hazard Prevention}

Risk Category 2

Safety documentation for equipment/system: $\square$ AHD $\square$ RWA $\square$ RWP $\square$ SAR $\square$ SAD

Lockout/Tagout considerations: Breakers $12 \mathrm{~A} 33$ and $12 B 23 \mathrm{C} 12$ must be locked out.

Toxic, flammable or radioactive substances used with equipment:

yes

Hazard prevention/environmental mitigation devices fitted:

\begin{tabular}{lcllc} 
Component & Quantity & & Component & Quantity \\
Rupture disks & 0 & & Press sensors & 3 \\
Pressure relief valves & 2 & & Temp sensors & 3 \\
Pressure regulator valves & 2 & & Flow sensors & 3 \\
\hline Pressure gauges & 2 & & Relays & 2 \\
Indicator lights & 3 & & Audible alarms & 1 \\
Panic/crash off switch & 2 & & Other
\end{tabular}

Safety systems related to safe operation:

$\begin{array}{lll}\text { Support Equipment interlocks (yes/no) } & \text { yes } & \text { Gas Monitors/Detectors } \\ \text { Electrical interlocks (yes/no) } & \text { yes } & \text { MDA\&Bad 80 } \\ \text { Radiation interlocks (yes/no) } & \text { no } \\ \text { Audible alarms (yes/no) } & \text { yes } & \end{array}$

\section{Additional Information}

Exhaust.gases piped to.cDo. for.safe disposal...MDA.gas detector.monitors gas concentration.in ro. 



\section{ATTACHMENT IV (FORM 3) - SAMPLE MAINTENANCE NEEDS EVALUATION}

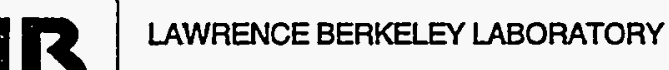

\section{Maintenance Needs Evaluation}

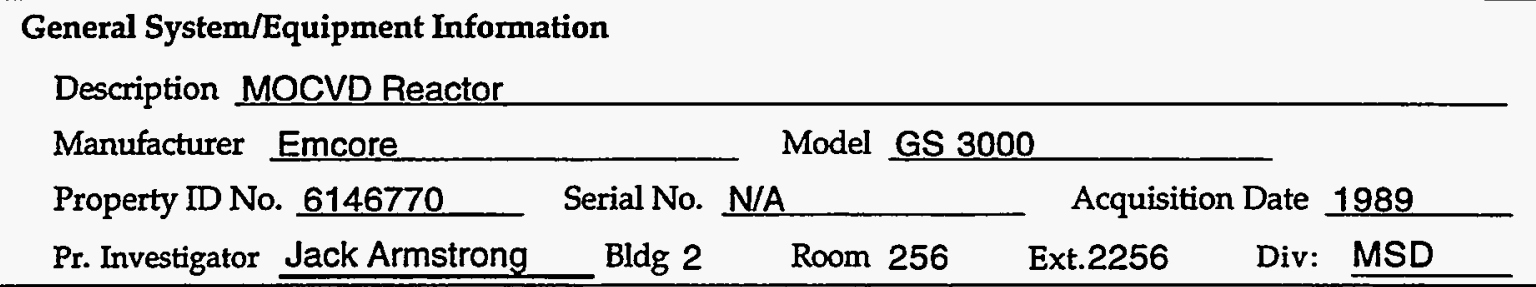

General Overall Maintenance

Frequency of use (will affect maint frequency): $\otimes$ heavy (daily) $\square$ frequent (weekly) $\square$ occasional Maintenance performed by: $\square$ Service Contract with:

$\otimes$ In-house personnel trained for calibration/maintenance

$\square \mathrm{M} \& \mathrm{O}$

Maintenance procedures:

Training verified:

冈mfr manuals

$\square$ in-house developed

$\square$ other:

Location of Procedures/Manuals: In cabinet next to equipment.

Location of Repair History Records: Maintenance logbook in cabinet beside equipment

Specialized Maintenance Requirements (especially for Hazard Prevention Devices)

General failure causes of components

not available

Special maintenance procedures required/other regulatory requirements affecting maintenance See Appendix A in the manufacturer's manual.

Special tools and testing equipment required

Special tools and equipment are listed in Appendix B of the manufacturer's operating manual

Special training or certification required

Training by manufacturer's representative is presently required. After proper training by the manufacturer's representative, $\perp B \perp$ lab technicians will become the instructors 



\section{ATTACHMENT IV (FORM 4) - SAMPLE MAINTENANCE PROGRAM SCHEDULE}

\section{IB \\ Maintenance Program/Schedule}

\begin{tabular}{|c|c|c|c|}
\hline \multicolumn{4}{|c|}{ General System/Equipment Information } \\
\hline Manufacturer Emcore & & Model GS 3000 & \\
\hline Property ID No. $\underline{6146770}$ & Serial No. & & Acquisition Date 1989 \\
\hline Pr. Investigator Jack Armstrong & & Div: MSD & Room 256 \\
\hline
\end{tabular}

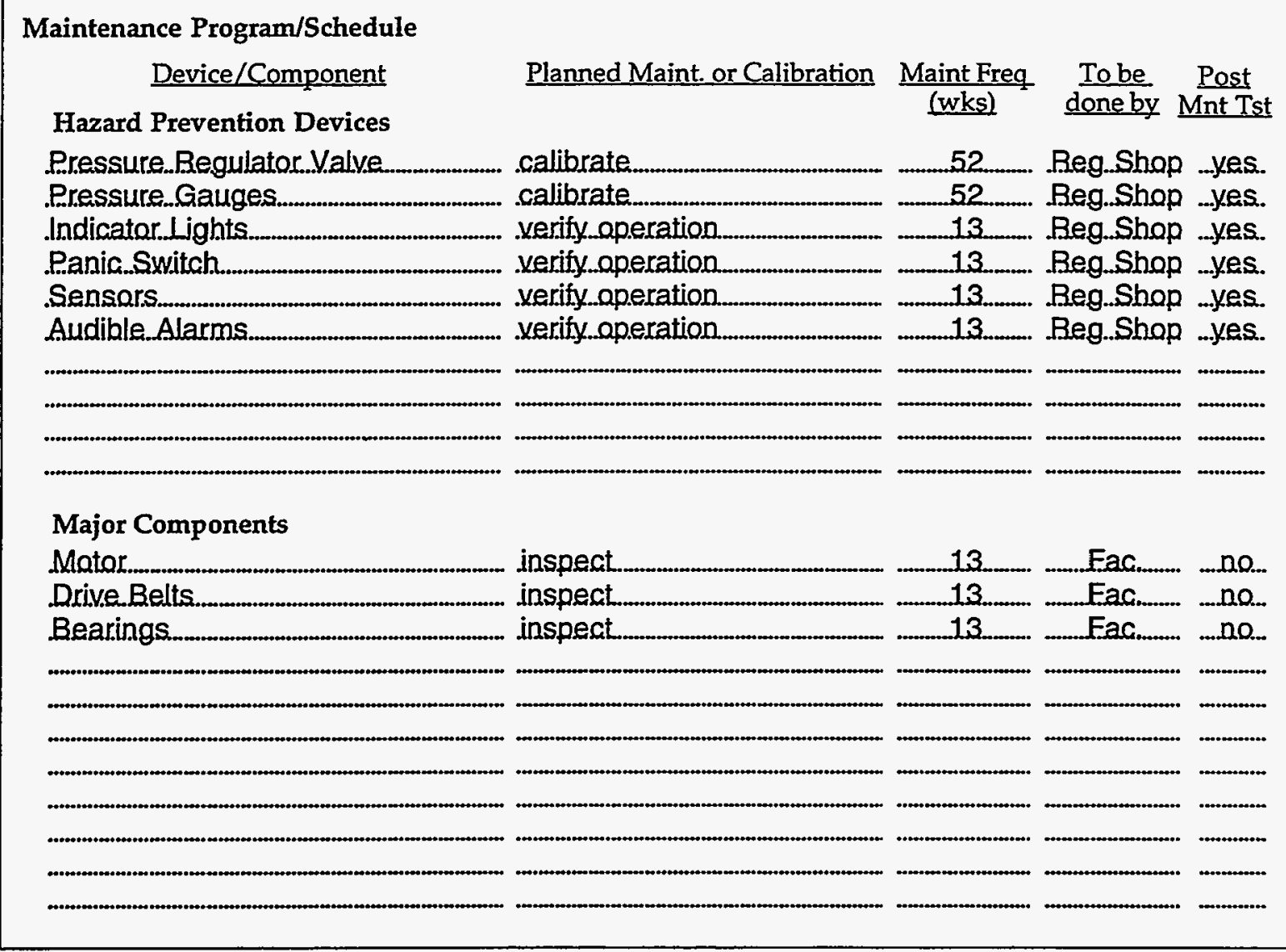

Additional Information

Exhaust gases piped to CDO for safe disposal. CDO to have maintenance with MOCVD. 



\section{ATTACHMENT IV (FORM 5) - SAMPLE EQUIPMENT MAINTENANCE}

RECORD

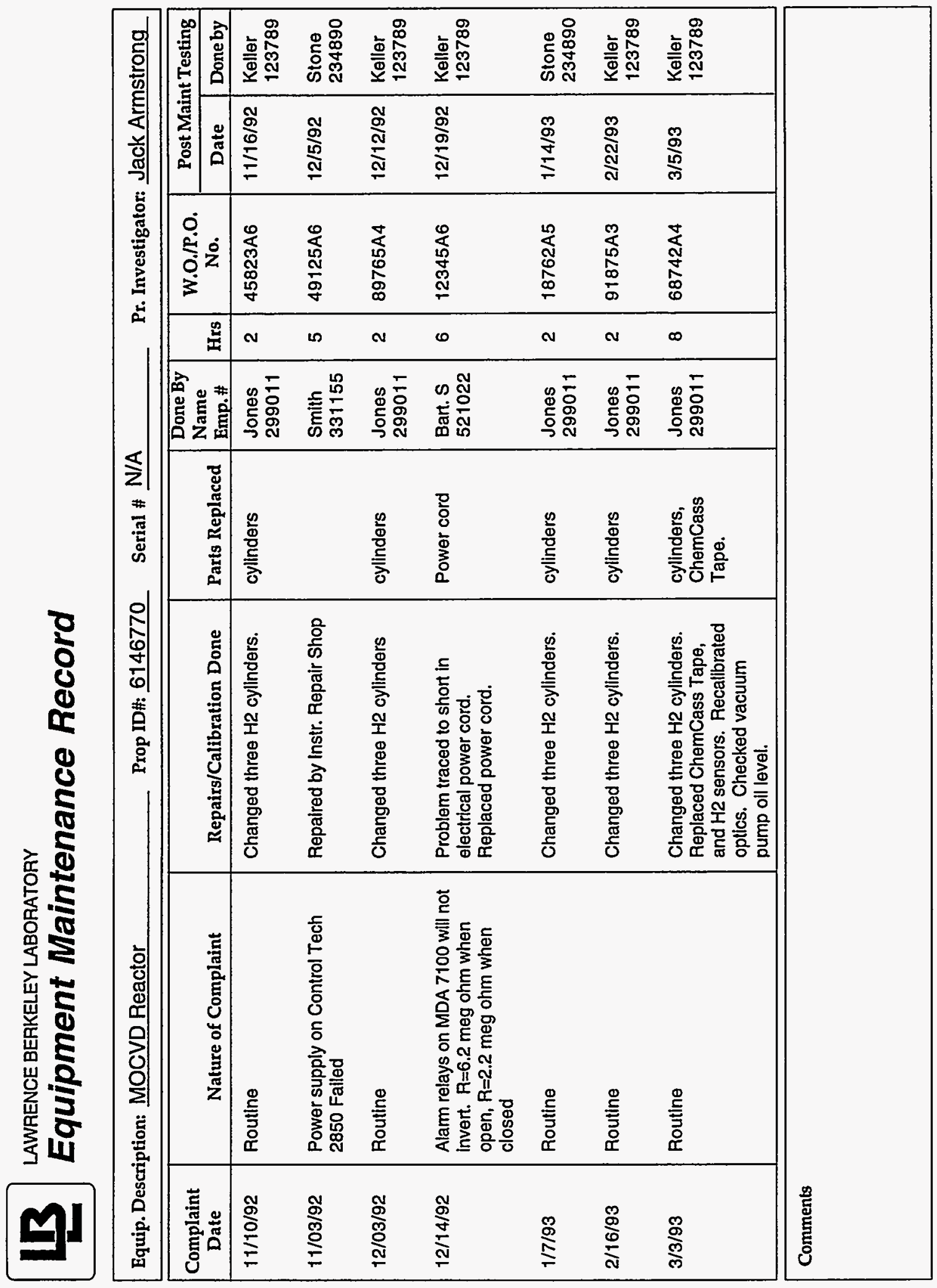

